\title{
The Absence of Decent Work: The Continued Development of Forced and Unfree Labour in India
}

\author{
Jamie Morgan, Leeds Beckett University, United Kingdom \\ Wendy Olsen, University of Manchester, United Kingdom
}

\begin{abstract}
The International Labour Organisation (ILO) has developed a concept of decent work and set this as a standard in 1999. However, in many places in the world people labour under conditions that are far from 'decent'. Many people are subject to forced labour and experience unfreedoms, which raises important theoretical and practical issues. In this contribution we set out some of the ways in which forced labour manifests and how it has been changing over recent years in India. India is of particular interest because, according to the ILO, Asia, and India within Asia, has more victims of forced labour than any other region. India illustrates that specific structures of social relations underpin one's vulnerability to becoming a victim of forced labour. It illustrates also that forms of forced labour integrate into and develop within capitalism. Although neo-liberal policy prescriptions are formally opposed to forced labour, the neo-liberal capitalist system also facilitates its reproduction and spread.
\end{abstract}

\section{KEYWORDS}

Unfree labour, forced labour, ILO, India

The International Labour Organisation (ILO) has developed a concept of decent work and set this as a standard in 1999 (Ghai, 2006). However, in many places in the world people labour under conditions that are far from 'decent' and it is this on which we focus here. Many people are subject to forced labour and experience unfreedoms. This raises important theoretical and practical issues. In this paper we set out some of the ways in which forced labour manifests and how it has been changing over recent years in India. India is of particular interest because, according to the ILO, Asia, and India within Asia, has more victims of forced labour than any other region. India illustrates that specific structures of social relations underpin one's vulnerability to becoming a victim of forced labour. It illustrates also that forms of forced labour integrate into and develop within capitalism. Although neo-liberal policy prescriptions are formally opposed to forced labour, the neoliberal capitalist system also facilitates its reproduction and spread.

The empirical material presented here is based on a synthesis of observations from longstanding field research conducted in India by present author Wendy Olsen and also work by a range of colleagues (e.g. Barrientos, 2011; Phillips, 2011; Guerin, Ponnarasu, Venkatasubramanian and Michiels, 2012). In the first section we define unfree labour and forced labour, which is usually measured by ILO criteria. These concepts overlap. In the second section we set out some of the 
conceptual issues regarding forced labour and unfreedom. Existing theories explain unfreedom well, but we add that certain nuances of social structures influence the details of the growth and waning of forced labour. Towards this end, in the third section we provide details of India's social structure, showing how structural features are currently supportive of unfree labour there. Finally we explain some particular ways in which unfree labour practices are reproduced and transmitted from context to context in India. These illustrate that:

1. Unfreedom is not simply a consequence of being trapped in pre-capitalist relations in traditional contexts, but can arise because life chances are bound up with the way the whole of society and economic opportunity are configured.

2. The dominance of the informal economy in India is a key context within which unfreedom has both persisted and developed.

3. On an individual and household level people now experience shifts in and out of unfree situations in ways that are configured by combinations of existing structured circumstances, becoming more or less indebted, more or less vulnerable to exploitation.

\section{The ILO and Forced Labour}

The ILO first defined forced labour in its 1930 convention (No. 29; Article 2(1)) and has continued to elaborate upon it since (ILO, 2005, 2009). The ILO's notion of forced labour is an attempt to translate the broad category of unfree labour, which appears in political economy and sociological theory, into a more legal and institutional form. Unfree labour is delineated with reference to three key characteristics (Lerche, 2007; Strauss, 2012):

1. Labour is unfree if current employment relations were not freely entered into; the worker was sold, born, onerously obligated, coerced or deceived into the work situation.

2. Labour is unfree if the worker is not free to exit the current employment relation and enter into alternative employment relations; they are entrapped.

3. Labour is unfree if the terms and conditions of current employment are onerous, violating the worker's human and legal rights, significantly harming the well-being of the worker while also contributing to the continued entrapment of the worker in the employment relation.

All ILO forced labour would be classified as unfree, but the terms used differ for historical and legal reasons. The characteristics of unfreedom are general but can be found in multiple combinations and contexts. In all, 'not freely entered into' and entrapment mean more than simply taking employment because of economic necessity and poor working conditions, or feelings of inability to relinquish that employment. Being induced to work through poverty could easily conform to Marx's basic concept of free labour within capitalism. He noted that workers have the freedom to starve unless they contract their labour power. There must be some further identifiable violation. It is here that the ILO tends to look for indicators and these are expressed as reasons to consider labour to have been forced (ILO, 2005: 6, 2009: 13). Key indicators include retention of documents, isolation, physical or implied threat to self or family, and, often, manipulation of pay and of debt (where the latter is made impossible to repay (see also UN, 1957: 41).

The ILO groups forced labour into three categories (Belser, 2005): 
- Imposed by the state/state challenging rebel factions - typically for military purposes or for public works through prisons

- Commercial sexual exploitation (CSE) - typically forced prostitution of adults and children

- Non-sexual economic exploitation (EE).

For statistical purposes these categories are also cross-referenced with the existence of trafficking, based on the United Nations (UN) Palermo Protocol of 2000. According to the ILO (2012: 16), globally there were 20.9 million victims of forced labour in 2012, of which 14.2 million were victims of EE, 4.5 million of CSE and 9.1 million were trafficked. The ILO also acknowledges that its statistics likely significantly underestimate the true scale of forced labour. The nongovernmental organisation (NGO), the Walk Freedom Foundation, for example, produces a Global Slavery Index; based on studies for 162 countries, it provides an estimate of 29.8 million victims of forced labour (Walk Free, 2013). Significantly, most individual states, and global institutions are formally opposed to forced labour. Free labour is a core constituent of capitalism as a system, and the ideological framework of democracy requires free individuals with a range of formal rights for its legitimacy. The very existence of forced labour and the experience of unfreedom bring the system into question. Yet forced labour, amounting to quasi-slavery, is found in almost all countries and all sectors of the economy. Any moderately informed reader of the press will be aware that it is both spreading across states and also shifting from sector to sector.

\section{The Context of Forced Labour as a Concept: Neo-liberalism, Economism and Critical Approaches}

Given that forced labour does not seem to be simply disappearing but rather continues to be reproduced in some places, and is emerging in other places, it is simply not credible to consider forced labour only as a vestige of pre-capitalist relations. It is a manifest reality within capitalism and can become integrated into capitalism. However, capitalism is not an undifferentiated system. Capitalism is a system that varies in some of its constituents in time and place. It then follows that some forms of capitalism and some features of capitalism are likely more conducive to forced labour than others. The present world system with its dominant neo-liberal ideology clearly has characteristics that facilitate forced labour and unfreedom (Morgan and Olsen, 2014; see also Harvey, 2007, 2011; Jessop, 2005, 2007, 2012; Morgan, 2013).

In this ideology, a reductive economism creates a theory-policy tension by seeing neoliberalism as a form of capitalism that expands an economic logic to all spheres of life. It does so based on a contemporary update of an idealised market concept. According to this logic, markets discipline and shape behaviour, providing efficient or seemingly best possible outcomes, and do so based on freely available, homogeneously assessed, and well-used information. Economic agents have the greatest incentive (self-interest) to acquire and appropriately use information and do so dynamically, learning from error. The state and state actors lack such incentives (unless marketised through public choice economics, synthetic markets, etc.), and so efficient private markets are counter-posed to inefficient government failure, and markets are introduced to solve previously non-market problems. Concomitantly, the weight of ideological pressure in terms of policy is towards limited regulation and self-regulation, and this remains the case despite the global financial crisis. In this sense, today's system can be called neo-liberal in spite of undercurrents of resistance.

The idealised market concept is one that sits uneasily with the reality of globally dominant large corporations. Moreover, the reality of a modern economy is one of complexity in information 
where limited information, disinformation and disempowered information can all arise in given circumstances. Information is not a neutral unit - a medium of exchange that facilitates a system of free exchange, it is a component in structures of power relations. Forced labour can flourish in the modern economy despite any basic (voiced) institutional repudiation. There are multiple contexts in which one might consider this: the potentials in long supply chains and outsourcing; the potentials in local black and grey economies, some of which involve activity that is proscribed (often prostitution), some of which use labour in proscribed ways (such as sweatshops), but all of which benefit from the interstices in local oversight which may extend to looking the other way because of personal relations or sense of common cause with the exploiting group, or merely for the right price. The mobility of capital and labour, financialisation as instrumentality, and technocratic demarcations and the issue of responsibility are also part of reductive economism.

The economism of a neo-liberal system is also one that embraces a dualism in terms of how problems are solved. Recognised or identified problems become limited market failures requiring a technocratic fix, and so issues such as forced labour become subject to policy units and special measures. The problem is not posed as one of the system of markets whose general context is problematic in terms of all labour, but of this particular mechanism of failure. Absorbing the problem into policy units reduces the scope for democratic debate and responsibility regarding the general standards of the market system, from which forced labour emerges as a more egregious manifestation of the general tendency to treat labour as a unit cost (and where the system at large is antithetical to unions). In so far as debate concerning general standards diminishes, the potential for the emergence of egregious manifestations continues to persist, so the potential for forced labour remains because of the limited way in which it is addressed even when recognised. Moreover, once responsibility is absorbed into policy units then the problem of competition for state resources arises (units, special initiatives, task forces and so on can quickly become chronically underfunded, understaffed or under-supported as components in small government). Thereafter, a technocratic approach to problem solving leads to fragmentation rather than genuine unified opposition to the eradication of forced labour. Opposition remains located in organisations such as the ILO and in the formal commitments of rights inscribed in supranational organisations and in law.

Genuine unified opposition would imply proposing a different kind of system where the very concept of labour is given close linkages to the ILO's established concern with dignity. Neoliberalism is antithetical to this. At the same time its marketisation promotes a further dualism in terms of the responses of agency. In a general sense, neo-liberalism as a form of capitalism encourages or socialises a self-interested egoistic individualised identity in which one is alienated from others and so others can be dehumanised or their fates simply ignored (and a sense of geographical, social, and cultural distance, as well as financialisation, can facilitate this). Meanwhile there is also a consumption-based identity response to forced labour. The economic agents can choose to inform themselves of the labour practices of the producers of the goods and services they choose to consume, and so can base their consumption choices on a set of responsive ethical criteria. This then follows a market information logic to create signals for firms to ensure they are ethical in their conduct. However, the very possibility of such a lifestyle politics approach to ethical consumption indicates something about the generalised conditions of production: one is being invited to seek out non-exploitative goods and services, and it is possible to differentiate oneself as a niche consumer or producer on the basis of non-exploitation. The terms of exploitation, meanwhile, are ultimately defined by the way it is capitalism and not democracy that dominates neo-liberalism and this has remained a point of tension for such organisations as the World Trade Organisation (WTO), World Bank and International Monetary Fund (IMF). 
The general point then is that neo-liberalism may not be required for forced labour to occur but forced labour does more than merely persist in a neo-liberal period. The same can be said for unfree labour. Here, we use the terms interchangeably, forced labour being one used in policy circles and unfree labour being one used when the issues of freedom/coercion are treated theoretically and not just in terms of legal cases and counting (Skrivankova, 2010: 7). The dynamics of the system create opportunities. To persist and grow, forced labour must also be profitable. In 2005, the ILO provided its first global estimate of US $\$ 44$ billion in annual profits from forced labour. This was updated in 2009 and in early 2014 using some of the data from the 2012 estimate of the number of victims of forced labour (excluding the state category); the new estimate was US $\$ 150.2$ billion in annual profits (ILO, 2009, 2014: 13).

Beyond the general point there are many additional conceptual issues one might consider here in different contexts regarding forced labour. One might, for example, consider some of the specific discursive aspects and consequences of theory. Here, one can trace the way political economy and economics theory have located forced labour and thus acted to condition attitudes to it in ways that have then also been expressed in the neo-liberal period. Brass (2009), for example, makes the case that the classical political economy of Smith and then Mill assumed that a system of production based on unfree labour (such as feudal estates and plantation slavery) was inefficient and hence costly because the labourers had no incentive to maximise their productivity or to contribute to innovation. As such, unfree labour was something antithetical to capitalism. However, the terms of the argument rest on a failure to appreciate the very different ways in which activity can be motivated. Forced labour involves coercion and psychological menace, and as such there can be many reasons why a person will be productive. Furthermore, the argument is open to reversal. If one can establish that particular forms of non-capitalist organisation can be profitable one can then use this to infer that a form of organisation (slavery) is efficient under some description within economic theory. Conrad and Meyer provide an early example of this in the 1958 paper 'The economics of slavery in the ante bellum South'. They apply modern capital theory to the problem and construct two production functions for slaves (production of a staple crop and production of an intermediate good - slave-breeding). They then explore a dataset that divides the South into two based on regional specialisation, where the Old South became more of a slave-breeding area and the West a cotton-raising area, and the two may (the proposition is conditional) have operated through transfers as an allocatively efficient market in terms of the marginal efficiency of capital.

Conrad and Meyer's intention was to highlight that slavery could be efficient in comparison to industrial development (i.e. similarly profitable and so involve no pressure for a shift of resource use), and so one could not simply assume that its inefficiencies would cause pre-capitalist systems of economic organisation to simply wither away. In areas of the world where such situations persisted, it might require 'harsh political measures' to eradicate slavery (Conrad and Meyer, 1958: 122). However, the form of the argument has three undesirable consequences that have influenced later theory. First, slavery is contrasted with industrial development, neglecting the notion that one might find forced labour within capitalist organisation (it remains an argument that slavery is a vestige). The more nuanced understanding that forced labour is a set of characteristics of a labour relation rather than merely a corollary of a form of one type of organisation is ignored. Second, the form of the argument focuses on an economic concept of efficiency and the productivity of the slave, and this invites a further conformity of the conceptualisation of forced labour to economics theory; specifically the slave becomes a rational actor within the instrumental and calculative methodological individualism of theory. Within the constraints of this way of theorising, slaves choose to optimise outcomes (seeking to better themselves based on constraints; a curious notion since choosing within oppressive conditions is neither an issue of consent nor of appropriate context that focuses on the 
significance of freedom from compulsion, which constitutes the slavery). One finds this approach in the work of Fogel and Engerman (1974). Third, this approach fits a longer-term discursive trend within economics; specifically it forms part of both the increasing narrowness and technical specification of economics theory as part of what is variously termed mainstream economics or (loosely) neoclassical economics. It illustrates a general tendency within that mainstream to expand its domain of inquiry to colonise other fields; in this case socio-economic history is using cliometrics.

Cliometrics applies statistical analysis using econometric techniques to historical data sets in order to test hypotheses (Lyons, Cain and Williamson, 2008). Despite claiming to be sensitive to the problem of appropriate use of data and of inference, cliometrics has promoted revisionist histories based on highly contestable assumptions about the nature of human motivation that do violence to a fuller account of the actual context of social and economic relations. In so doing it serves also to delegitimise contextual debate regarding the actual forms of forced labour that have occurred and that are occurring. In so far as debate does occur it can become mis-focused by virtue of the tools of analysis. For example, within development studies economics, Biswajit Banerjee has produced numerous well-intentioned works on aspects of discrimination and migration in India using various aspects of choice theory (Banerjee and Knight, 1985). One might argue then that economic imperialism (the spread of an economistic mindset) serves as a distraction that provides inappropriate conceptual tools for understanding contemporary forced labour.

However, a more critical vein of analysis can also be found in development studies, sociology and political economy. Here, the term unfree labour is typically used and many important insights have been pursued. Forced labour may be an attempt to translate the concept of unfreedom, and this has its uses. But if one considers the ILO as an organisation, its focus on measuring forced labour through identifying indicators tends to put aside the different ways one might seek to explain and understand unfreedom. For example, Blackburn (1988, 1998) establishes that slavery and capitalism have not been alternative systems, but rather have historically co-evolved and integrated. Steinfeld (2001) explores how the notional free contract in capitalism has historically often involved coercion. Marcel van der Linden (2008) has developed a range of ways to categorise labour within capitalism, and with Bremen (2014) has then made the case that the majority of the world's population have never actually experienced the kind of formal employment relations that are taken by economic theory to be standard (and thus one might say equivalent to free labour). Their experience has been one of informality of employment relations (see later, and also Agarwala, 2013).

There are then many ways in which one might consider unfreedom to be possible within general processes of circuits of capital, and within specific regimes of production and accumulation. These create scope for labour to serve specific functions that gives some sense to how one might be described as unfree and where forced labour might be located. Brass, for example, explores how unfree labour can be functional within capitalism based on its role in class-consciousness and struggle:

Deproletarianisation occurs as a result of workforce restructuring, a form of class composition/ decomposition/recomposition which accompanies the struggle between capital and labour, and a process whereby employers introduce or reintroduce unfree relations. This is effected either by replacing free workers with unfree equivalents, or by converting the former into the latter. The advantages of deproletarianisation are twofold. Economically, such restructuring enables capitalist producers to lower the cost of free workers by employing more easily regulated, and thus cheaper, unfree labour. Ideologically, its purpose - in both metropolitan capitalist countries and third world contexts - is to prevent the emergence of specifically proletarian consciousness (Brass, 2002: 465). 
There has been considerable debate regarding the ideological role of unfreedom, but there has also been a great deal of work on the different ways in which forced labour is produced and also transmitted from one socio-economic context to another (for example: Brass 1999, 2002; Rao, 1999; Harriss-White, 2003; Banaji, 2003; Bremen 2007). It is this latter issue that interests us here. For many, decent work is currently not a realisable situation. In India, this is not simply because they are trapped in forms of pre-capitalist relations in traditional agriculture, but rather because life chances are bound up with the way the whole of society and economic opportunity are configured. This is an insight recently expressed by Lebaron and Ayers (2013: 874) who argue that unfreedom should not be viewed as merely an individual relationship of domination but rather as 'a social relationship of insecurity and exploitation', where 'the fluidity of unfreedoms characterising diverse modalities of labour exploitation in the capitalist economy' is significant. India illustrates some of the ways in which forced labour and the experience of unfreedom can develop. So, if we take as given the general adequacy of the more critical literature, with its focus on history, power and the evolution (or contingent development) of socio-economic conditions as framing constituents for the real possibilities and conditions experienced by people, we can then explore some (not all) of the specifics relevant to India. India is dominated by an informal economy, is a highly divided society, and has a whole set of contemporary characteristics that affect life chances and render some groups and persons more vulnerable to unfree labour outcomes. These can, as we illustrate, begin from more traditional rural contexts (though they need not) but then involve incorporation into different socio-economic contexts within capitalism. We begin by setting out some contemporary characteristics of India. Consider the following in terms of the impact on difference and life chances.

\section{Forms of Forced Labour in India}

As one of the BRICS economies, India has been regularly identified as a major source of dynamism within the global economy (Jain, 2006). According to the 2011 census, India's population now exceeds 1.2 billion, speaks 22 different languages and observes six major religions. Just over $50 \%$ of the population is under 25 years of age, approximately one-third of the population is under 18, and 160 million are under six years old. Unlike the majority of developed nations and also China, the proportion of India's working-age population seems likely to continue to grow (Bloom, 2011). By 2035 India's population is estimated to reach 1.5 billion, of which approximately $65 \%$ will be of working age. However, this is only a potential benefit to the population and the nation if, on the one hand, the young are adequately educated, and on the other, there is some form of viable economy for the growing population to integrate into. India is facing the same kind of pressures of human capital, job creation and investment that underpin the more familiar claim that China has required $8 \%$ economic growth in order to maintain social stability.

India has become an economy of growing abundance in some senses, but one where the experiences of the many do not reflect the potential benefits of economic growth. For example, class and caste differences remain significant (Morgan and Olsen, 2011b; Olsen and Morgan, 2010). Though caste discrimination is prohibited by the Indian constitution, hereditary caste demarcations are still recognised and widely observed; below the formal castes, 166 million dalits or 'scheduled castes' and over 84 million designated within 'scheduled tribes' still suffer systematic discrimination reflected in all measures of life chances and outcome, despite a political system that formally subscribes to policies of positive discrimination. Here, one might consider India to be a society and economy with only some features of capitalism. But it stretches credibility to analyse India in terms of 
a focus on ideal forms of a system in the abstract after 20 years of economic liberalisation and over 60 years of democracy.

According to the Global Slavery Index, India has more victims of forced labour than any other country in the world, with an estimate of 13.3 million to 14.7 million (Walk Free, 2013). As the 2012 ILO report also emphasises, these victims are found in every area of the economy. The following section synthesises observations regarding forced labour drawn from several strands of our own and colleagues' longstanding field research in India. The aim here is to illustrate the range and development of forms of forced labour, rather than to cover all possible aspects or instances. The section begins with rural-based forms of forced labour and tracks the way the rural poor then integrate into the broader informal economy through migration. We adopt this approach because it allows us to construct a narrative of the way unfree outcomes can develop within a range of contexts that go beyond traditional debt bondage (though we are not claiming all such relations begin in rural contexts). Households and persons can transition into and out of unfree situations and experience various kinds of forced labour. This is occurring in a country that is now a constituent of global neoliberal capitalist relations. A such, the general points we made above regarding the tendency of neoliberalism to facilitate forced labour should be kept in mind. India also has its own characteristics and these affect the way in which experiences of unfreedom develop. The more critical literature cited in the second section provides excellent context for considering this.

The points made are based on a combination of field research in two rural villages in the state of Andhra Pradesh, conducted periodically since 1985 (Olsen, 1996; Olsen and Morgan, 2010), field research conducted in the Nashik district of the state of Maharashtra, and in the capital city of that state, Mumbai (Reddy and Olsen, 2012), as well as fieldwork conducted in Chennai, the capital city of the state of Tamil Nadu (Harris-White, Olsen, Vera-Sanso and Suresh, forthcoming). The field research was conducted as qualitatively based semi-structured interviews involving multiple field researchers and as part of a series of projects funded by a variety of bodies. Fully anonymised versions of some of the materials are deposited with the ESRC Data Archive.

The most immediately recognisable form of forced labour in India is found among rural farming households. Rural farmers are differentiated by class and caste. In village life, the landlord class typically has sufficient property and wealth so that they do not work their own land. The absence of manual labour then also carries cultural significance and is usually reinforced by the caste status of the landlord (upper or forward castes). Landlord households typically exhibit a complex connection of familial, class and caste connections creating an information and influence network extending through the village and beyond, and based on inter-marriage and more general migration patterns. Ryot farmers are a social class who own and work sufficient land that they do not need to engage in casual labour. Worker farmer households meanwhile own or lease land but must also engage in casual and seasonal labour in order to survive. This class tends to include members of lower or backward castes. Below worker farmer households are tenant farmer households that rent smaller holdings and do so based on informal contracts with landlords. These and landless labourers tend to be dalits (the lowest-ranking hereditary stratum of society) from scheduled castes. They traditionally occupy separate cultural and physical spaces to other classes and castes.

It is the smaller tenant farmer households and landless labourers who tend to be subjects of the most readily recognisable form of forced labour - debt bondage. In order to maintain the tenancy, or to maintain access to other necessary elements for the viability of the household (e.g. additional grazing land or water sources), the household might be expected to do unpaid labour for the landlord on his other land or at his home. Formal contracts are rare and oral terms are often ambiguous. Conditions are often readily recognisable in terms of the ILO 1956 Supplementary Convention on debt bondage in the sense that 'the value of those services as reasonably assessed is 
not applied towards the liquidation of the debt or the length and nature of those services are not respectively limited and defined.' The tenant might also receive advance payments that are then spent on seed, fertilizer, equipment, and living. The sums may need to be perpetually renewed and thus be impossible to clear. In traditional debt bondage, debts pass from generation to generation. The problem can be exacerbated by the landlord's control of accounts, by opaque interest payments or by simple illness, injury or crop failure (which then renders the household vulnerable to accepting further and onerous obligations). Thus the household can easily be entrapped. The 1930 ILO Forced Labour Convention emphasises that the situation is more than one of low wages, poor working conditions or simple economic necessity. For tenant farmer households and landless labourers the situation is often one of exploitations of asymmetrical power relations. Power is not just rooted in land ownership, but in control of debt and also by implied threats and actual actions based in and designed to maintain class and caste distinctions. Poor levels of literacy and innumeracy exacerbate the problems, as does (though decreasingly so) a lack of awareness of any actual rights, or in some cases the inability to ensure enforcement by local officials.

Significantly, though the basic framework of rural bonded labour is not new, forced labour has developed based on changing conditions. Previously, bonded labour, though unfree and oppressive, was a relatively long-term and secure form of tenancy, involving generations of households. However, over the last 20 years the security of tenancy has reduced as landlords have looked to use their land in more flexible ways. Tenant labour can be coerced based on the perpetual threat of loss of tenancy. Landlords tend to dictate the crops produced on leased land and increasingly focus on cash crops. Tenants find it difficult to use significant portions of the land for subsistence. Furthermore, cash crops, in the post Green Revolution era, tend to be dependent on seed purchase and chemical fertilizer, raising the upfront costs of farming. Additionally, these crops can be highly irrigation-reliant. Thus, both the potential costs of tenant farming and the vulnerability to crop failure are accentuated. This has further been exacerbated in the last ten years by significant regionalised droughts in India. The combination creates the potential for debt spirals locking the tenant into future labour in order to try to recoup losses which were incurred to advantage the landlord but which are attributed entirely to the tenant. The conditions or practices are thus both onerous and entrapping, creating characteristics 2 and 3 of an unfree labour situation from the first section.

Tenants are channelled into forced labour based on their vulnerability - that is, their social positioning within social relations. Caste and class both position the household as economically vulnerable because particular castes and classes lack material assets. They also lack cultural power within the village context. However, though many of the most vulnerable are poorly connected and poorly educated, and these characteristics are exploited by landlords (particularly in terms of interest rates and denying rights when appealing to local officials), the vulnerable are neither passive nor simple dupes. Extensive interviews indicate that many are strongly aware of their entrapment, are often resistant to the practices in which they are entrapped, and are highly critical regarding the social relations that contribute to their entrapment. Often they situate their position in terms of previous generations of their family, stating that they do not wish to accept the conditions about which their forebears were (by their own admission) more passive.

They see opportunities in two different contexts. There are new dynamics within rural life for example, the role of self-help groups, microfinance and small-scale local development projects, supported by NGOs within umbrella organisations supported by the state, the World Bank and so forth (Morgan and Olsen, 2011a). And there is the pull of migration, where some of the household spend some or all of their time elsewhere working in some aspect of India's developing economy. Remitted income creates the potential for the household to develop material assets and improve its 
circumstances, escaping both current forced labour and poverty. The use of both microfinance and migration ostensibly offers the opportunity to escape the most readily recognisable forms of rural forced labour, typically rooted in debt bondage. The conditions of opportunity, however, are not simple liberations because the ability of households to engage with them is structured by a household's existing circumstances and the nature of the economy participants are then incorporated into.

\section{Migration Gangmasters and Indian Innovations of Forced Labour}

The conditions of opportunity offered by local development projects can produce new forms of debt vulnerability. For example, microfinance can offer a route out of debt bondage. Equally, however, it can provide the means for a household to emerge from bondage and then sink back into new forms of forced labour on a cyclical basis. The limitations and failings of microfinance can create new debt vulnerabilities that channel the vulnerable either back into traditional debt bondage or on into new forms of forced labour (Geruin, Kumar and Agier, 2013; Morgan and Olsen, 2011a; Roy, 2010). As the nature of tenant farming becomes more precarious and as the rural poor become more aware of the opportunities to earn income elsewhere, a pattern of migration emerges. On a seasonal or possibly sporadic and casual basis, or as an intended temporary but relatively long-term commitment, some or the entire household take up employment elsewhere. If it is only some of the household, then the intention is to remit income. In the meantime, however, a greater burden of work and family responsibility falls upon those left behind, who continue to work as tenant farmers. Typically this means that women face that greater burden - there is then a gender dynamic to the impacts of the developing situation. In these circumstances it is women, children and the elderly who experience much of the day-to-day direct pressures of any situations of unfreedom that arise in and around the original location of the household. The domestic context of vulnerability to forced labour becomes a matter of the ability of women in particular to resist the pressures to fulfil informal obligations to landlords, while also seeking to balance a precarious existence of tenantbased work against a backdrop of multiple sources of debt (loans from landlords, from local userers, and from microfinance sources). Remitted income becomes a part of an ongoing balancing act as a better future is sought.

However, the positioning of different agents also influences the process of seeking a better future. The conditions of opportunity are not simple liberations because the ability of households to engage with them is structured by their existing circumstances. There is no simple and necessary liberation from forced labour as individuals and households are incorporated into a changing economy through migration, leaving behind rural debt bondage. The economy itself is one structured to incorporate labour in unfree ways; as Lebaron and Ayers (2013) argue, unfreedom should not be viewed as merely an individual relationship of domination and there are diverse modalities of exploitation. As Brennen and Van der Linden (2014) note, this is facilitated by the absence of the formal employment relations that are taken as typical for capitalism (but for the majority world are simply not). Here, those experiencing unfree conditions can readily be seen to serve Brass's (2002) deproletarianising function, while also serving as a source of profitability, through unit cost effects, for broader chains of capitalist productive activity, and also as a source of profit for immediate exploiters. It is to these we now turn.

For the rural poor a parallel agent who occupies a relatively powerful relational position typically mediates their agency; this is the 'maistree' [a word related to the English 'master'] or gangmaster. The power of the maistree operates in various ways. Typically, the maistree is subcontracted by an employer to deliver a given number of workers for some specified period. In a 
formal sense, if one subscribed to mainstream economic theory, the maistree is an intermediary resolving an allocation problem by overcoming both an information asymmetry between worker and employer and any further specific mobility constraint that the worker may be subject to. The maistree makes potential workers aware of employment, provides transport over what may be considerable distances, and typically provides workers with an upfront payment to secure their participation.

However, like gangmasters in many situations around the world (for example, those who recruit from Mexico into the United States), the maistree is positioned to integrate unfree labour practices for participants and to the maistree's gain. Upfront payments are a 'rational response' by the maistree in order to guarantee participation in economic migration. Participants, however, may rely on them and use them for subsistence during the lean part of the year when casual work is less available and harvests are not due. Participants have thus used up some proportion of their income prior to the working period for which it is due. Debt is not always a sign of bondage nor is it necessarily indicative of forced labour or associated with the three characteristics of unfree labour. However, debt creates a vulnerability to exploitation based on the further characteristics of the situation. It creates dependence and also the opportunity for manipulation. Maistree, like landlords, are able to exploit the situation in a variety of ways. Workers are often partially or wholly illiterate and sometimes innumerate. Maistree control the record keeping for debt and are able to apply interest as they see fit. Additional costs may be incorporated into the debt without prior clarification. For example, the costs of transport to the work destination, which may be in a different state, might also be placed on the participant. As such, the debt can quickly spiral, becoming an obligation to pay that outstrips the original upfront payments. Debt can then take on some of the aspects identified in the 1956 ILO Supplementary Convention where 'the value of those services as reasonably assessed is not applied towards the liquidation of the debt or the length and nature of those services are not respectively limited and defined'. Participants can then easily find themselves subject to the second of the three characteristics of unfree labour - that is, become entrapped - even though the form of labour they have set out to engage in appears in a formal sense to be free (wage labour at some designated site). The third characteristic of unfree labour may then also pertain, where the conditions of work are onerous and the worker's legal and human rights are violated. This may be maintained through any number of the elements of forced labour identified by the ILO from direct threats to 'subtler forms of menace, sometimes of a psychological nature'. Since maistree provide migrant labour across a variety of sectors, the problems are found in many types of work - from construction to outsourced labour-intensive assembly plants and varieties of small sweatshops for textiles and small crafts.

Interview data establishes that the problems are many (Guérin et al., 2012; Barrientos, 2011; Phillips, 2011; Reddy and Olsen, 2012). The participant may be designated as an employee of the maistree rather than the actual employer. Any formal employment rights to which the actual employer is nominally committed may then not apply. The maistree may also seek to extract further rent by minimising the wages of the participant as a proportion of their own payment from the employer. The participant may be unaware of this, and is not in a position to object for a variety of reasons. They will likely have no local assets and will live in tents, dormitories, barracks or temporary slum areas. If they attempt to act as free labour and seek alternative employment they will be rendered homeless while still indebted to the maistree. There may be a language barrier because the participant is not local, and this tends to mean that participants cannot easily seek alternative employment. This search constraint is a matter exacerbated by long hours of work and isolated living conditions; these conditions also prevent participants effectively organising to assert any rights they have, especially in matters of health and safety. 
Local officialdom can often be indifferent to migrant labour, partly because of language issues, partly because of perceived caste and class issues, and partly because individual labourers are temporary while the maistree and/or the sub-contractor are more permanent and powerful as a presence for local officialdom. Barrientos (2011: 7), for example, finds these factors to be common in the garment industry in Delhi where $40-50 \%$ of the workforce are likely to be migrants subcontracted to a maistree (here termed thekedaar), and are routinely denied formal employment rights while also working for wages 15-30\% lower than formally contracted labour. The factory itself occupies a low rung in a global supply chain. The use of sub-contraction within outsourcing tends to disguise the existence of forced labour from those further up the supply chain, since compliance to any labour standards can be nominally demonstrated. The worst-case scenario here was graphically illustrated by events in Bangladesh in April 2013. The collapse of the Rana Plaza building resulted in more than 1100 deaths. The building contained several garment factories supplying major Western brands. Despite signs of loss of structural integrity in the building, workers were compelled to remain inside. Similar issues are common in India.

The concept that a maistree resolves an allocation problem by overcoming an information asymmetry is one that is clearly deficient. In context, migrant workers lack both information and power to act on any information they may have. Moreover, when one considers from a sociological perspective how the maistree is positioned, then one can also appreciate the broader power dynamics rooted in social relations. The maistree's ability to act as an intermediary is rooted in networks. Maistree tend to be from the general areas in which they recruit, but they must also possess the skills and capitalisation to act effectively in their role as intermediary with the employer. As such, they tend to be better educated, and of higher caste and class than those they recruit. Their network can also extend to their relations, which may be familial, with the power hierarchy of the villages from which the recruits derive. There is, then, the potential for recruits to experience subtler forms of psychological threat regarding the consequences for them and their family of challenging the violation of their rights at work.

The net result of the relative positions of maistree and migrant is that the migrant is vulnerable to an outcome of unfree labour. There are a range of possible outcomes, including worst-case and best-case scenarios. In the best-case scenario the migrant is able to work in a manner that is more recognisably free and earn sufficient income to pay any debts incurred, as well as remit income, enabling the accumulation of assets and enabling the household to emerge from both poverty and rural-based unfreedom. Even here the work undertaken may be far removed from the ILO ideal of decent work and may involve significant exploitation and danger. In a worst-case scenario the migrant becomes entrapped in a pattern of forced labour within the informal economy (often servicing the formal economy). Importantly, an unfree outcome is not the result of any single process. It may be simply the result of obvious exploitation by the maistree. It may, however, be a more complex situation. For example, the household may become reliant on the remitted income because of the basic changes in rural conditions we referred to previously. The migrant may then be injured or become ill, and this is a common experience where work sites exhibit little concern for health and safety and where long hours are typical (a combination experienced, for example, in brick-kiln factories, smelting and construction). At this point the household simultaneously incurs additional medical expenses and the loss of a key contribution to debt servicing. The migrant shifts from a designation somewhere along the spectrum of unfree to free labour to simply unemployed, while the household as a whole may find itself landless, immiserated or simply increasingly vulnerable to accepting new obligations.

Those positioned in the most vulnerable ways, then, can experience cycles of more or less free and unfree outcomes. At the same time, there are clear commonalities in the underlying structural 
relations. For example, lack of education, lack of material assets, designation within lower castes and social classes. And there is clear commonality in the willingness of some to act as exploiters within an informal economy - an economy it should be emphasised, which may sometimes in some aspects appear to be formal. Here one might note that the lived experience of many within the Indian economy involves profound changes but also some basic continuities. The continuities indicate that even as change occurs a form of development is being pursued that is not effectively addressing some basic underlying problems of inequality (Verma, 1998; Olsen, 2009a, 2009b).

\section{Conclusion}

In this paper, we have set out a narrative structure that illustrates how forced labour can develop from traditional rural debt bondage to new forms in new contexts, some of which involve cycles. Forced labour is not disappearing. It is integrating into capitalism. Some remain more vulnerable to unfree outcomes than others and this is tied up with structures of social relations. At the same time some forms of development and of capitalism make unfree outcomes more likely. In the case of India the dominance of an informal economy creates opportunities for exploitation. On a global scale one might also note that a neo-liberal form of globalisation creates extended supply chains that are difficult to monitor and in which exploitation can flourish. And this is to say nothing of the problem of international human trafficking for sexual and economic purposes.

Solutions to the problems can come at many levels and we by no means wish to suggest that the Indian government has made no attempt to address forced labour. India has ratified key ILO conventions and translated its commitments into domestic law. However, criminal and civil enforcement requires resources, awareness, transparency and accountability. Enforcement is chronically under-resourced, exploitation is normalised and entrenched in local culture, officials and police are often part of the problem - since a web of payments within the informal economy can often be part of their income and to go against the unwritten rules on an individual basis can seem both pointless and against their own interests (US Department of State, 2011: 189). Many Indian states now have inspection teams focused on victims of human trafficking, forced prostitution and debt bondage. But as the annual Trafficking in Persons Report consistently indicates, prosecuted cases run to the hundreds, while the problem according to the ILO's conservative estimates involves millions of victims. An effective approach, therefore, requires funding more and better-educated specialised and incorruptible teams of inspectors, prosecutors and enforcement officers. But it also requires something be done about context. Criminal and civil enforcement are reactive rather than proactive. Liberating people from forced labour does not prevent them and others continuing to be vulnerable to such situations. Poverty, inequality and informality must also be addressed (Bhatia, 2012). It is social and economic empowerment and the development of decent work that will reduce the vulnerability. This is a national and a local issue. An effective education system, for example, keeps more children in school, raising the demand for adult labour. However, it is also an issue for transnational capitalism. Corporations should not be encouraged to simply withdraw contracts when caught using least-cost outsourcing based on exploitative labour practices. The basic tendency to seek out least-cost is then simply perpetuated. It is for this reason that the ILO seeks to bring together unions, employers and states (ILO, 2005, 2009: Chapter 4; Ghai, 2006). The UN and the ILO work to eradicate forced labour, and this is important. However, it is also important to recognise that the ILO's general orientation does not flow with the weight of the discursive and policy momentum of neo-liberalism. Economics theory is part of that weight; in addition, wherever mainstream economics theory is applied to the problems of forced labour, that problem is confused and deformed. 


\section{REFERENCES}

Agarwala, R. (2013) Informal labor, formal politics, and dignified discontent in India Cambridge: Cambridge University Press.

Banaji, J. (2003) 'The fictions of free labour: Contract, coercion, and so-called unfree labour', Historical Materialism, 11(3): 65-95.

Banerjee, B and Knight, J. (1985) 'Caste discrimination in the India urban labour market', Journal of Development Economics, 17(3): 277-307.

Barrientos, S. (2011) Labour chains: Analysing the role of labour contractors in global production networks, Brookings World Poverty Institute Working Paper 153. Manchester: University of Manchester.

Belser, P. (2005) Forced labour and human trafficking: Estimating the profits. Geneva: ILO.

Bhatia, B. (2012) 'Of human bondage in Baran, Rajasthan', Economic \& Political Weekly, 47(26-27): 159-169.

Blackburn, R. (1988) The overthrow of colonial slavery: 1776-1848. London: Verso.

Blackburn, R. (1998) The making of new world slavery: From the Baroque to the modern, 1492-1800. London: Verso.

Bloom, D. (2011) 'Population dynamics in India and implications for economic growth', in Ghate, C. (ed.) The Handbook of the Indian Economy. Oxford: Oxford University Press.

Brass, T. (1999) Towards a comparative political economy of unfree labour: Case studies and debates. London: Routledge.

Brass, T. (2002) 'Rural labour in agrarian transitions: The semi-feudal thesis revisited', Journal of Contemporary Asia, 32(4): 456-473.

Brass, T. (2009) 'Capitalist unfree labour: A contradiction?’ Critical Sociology, 35(6): 743-765.

Bremen, J. (2007) Labour bondage in West India: From past to present. Oxford: Oxford University Press.

Bremen, J. and Van der Linden, M. (2014) 'Informalizing the economy: The return of the social question at the global level', Development and Change, 45(5): 920-940.

Conrad, A and Meyer, J. (1958) 'The economics of slavery in the ante bellum South', The Journal of Political Economy, 66(2): 95-127.

Fogel, R. and Engerman, S. (1974) Time on the cross, Volume 1: The economics of negro slavery. London: Wildwood.

Guérin, I., Kumar, S. and Agier, I. (2013) 'Women's empowerment: Power to act or power over other women? Lessons from Indian microfinance', Oxford Development Studies, 41(1), 1-18.

Guérin, I., Ponnarasu, S., Venkatasubramanian, G. and Michiels, S. (2012) 'Ambiguities and paradoxes of the decent work deficit: Bonded migrants in Tamil Nadu', Global Labour Journal, 3(1): 118-142.

Ghai, D. (ed.) (2006) Decent work: Objectives and strategies. Geneva: ILO.

Harriss-White, B. (2003) India working. Cambridge: Cambridge University Press. 
Harriss-White, B., Olsen, W., Vera-Sanso, P. and Suresh, V. (Forthcoming) 'The impact of shocks on workers in urban slums in South India'. An online version is Olsen W.K., Harriss-White, B., Vera-Sanso, P. and Suresh, V. (2010) 'The experience of slum dwellers in Chennai under the economic and environmental insults of 2008-9', Work in Press Paper no 4, CSASP, SIAS Oxford. Available online at http://www.southasia.ox.ac.uk/_data/assets/pdf_file/0011/ 36587/Oxford_University_CSASP_-_Work_in_Progress_Paper_4.pdf.

Harvey, D. (2007) A brief history of neo-liberalism. Oxford: Oxford University Press.

Harvey, D. (2011). The enigma of capital and the crises of capitalism. London: Profile.

International Labour Organisation (ILO) (2005) A global alliance against forced labour: Global report under the follow-up to the ILO declaration on fundamental principles and rights at work 2005. Geneva: ILO.

International Labour Organisation (ILO) (2009) The cost of coercion: Global report under the follow-up to the ILO Declaration on Fundamental Principles and Rights at Work. International Labour Conference, $98^{\text {th }}$ Session 2009 Report I(B). Geneva: ILO.

International Labour Organisation (ILO) (2012) Global estimate of forced labour: Results and methodology. Geneva: ILO.

International Labour Organisation (ILO) (2014) Profits and poverty: The economics of forced labour. Geneva: ILO.

Jain, S. (ed.) (2006) Emerging economies and the transformation of international business: Brazil, Russia, India and China (BRICS). Cheltenham: Edward Elgar.

Jessop, B. (2005) 'Critical realism and the strategic relational approach', New Formations, 56:40-53.

Jessop, B. (2007) State power: A strategic relational approach. Cambridge: Polity.

Jessop, B. (2012) 'History and crisis in theory and practice', Paper presented at the IPEG Conference, Birmingham University, 10-11 September. Original available from the author.

Lebaron, G. and Ayers, A.J. (2013) 'The rise of a 'new slavery'? Understanding African unfree labour through neoliberalism', Third World Quarterly, 34(5): 873-892.

Lerche, J. (2007) 'A global alliance against forced labour? Unfree labour, neo-liberal globalization and the International Labour Organization', Journal of Agrarian Change, 7(4): 425-452.

Lyons, J., Cain, L. and Williamson, S. (eds.) (2008) Reflections on the cliometrics revolution. London: Routledge.

Morgan, J. (2013) 'Forward-looking contrast explanation, illustrated using teh Great Moderation', Cambridge Journal of Economics, 37(4):737-758.

Morgan, J. and Olsen, W. (2011a) 'Aspiration problems for the Indian rural poor: Research on selfhelp groups and micro-finance', Capital \& Class, 35(2): 189-212.

Morgan, J. and Olsen, W. (2011b) 'Conceptual issues in institutional economics: Clarifying the fluidity of rules', Journal of Institutional Economics, 7(3): 425-454.

Morgan, J. and Olsen, W. (2014) 'Forced and unfree labour: An analysis', International Critical Thought, 4(1): 21-37.

Olsen W. (1996) Rural Indian social relations. Delhi: Oxford University Press. 
Olsen, W. (2009a) 'Non-nested and nested cases in a socio-economic village study', in Byrne, D. and Ragin, C. (eds.) Handbook of case-centred research methods. London: Sage.

Olsen, W. (2009b) Beyond sociology: Structure, agency, and strategy among tenants in India', Asian Journal of Social Science, 37:3, 366-390.

Olsen, W. and Morgan, J. (2010) 'Institutional change from within the informal sector in Indian rural labour relations', International Review of Sociology, 20(3): 535-555.

Phillips, N. (2011) 'Informality, global production networks and dynamics of adverse incorporation', Global Networks, 11(3): 380-397.

Rao, M. (1999) 'Freedom, equality, property and Bentham: The debate over unfree labour', Journal of Peasant Studies, 27(1): 97-127.

Reddy, B. and Olsen, W. (2012) 'Adaptation of the rural working class in India: A case study of migrant workers", in Clark, D. (ed.) Adaptation, poverty and development: The dynamics of subjective well-being. London: Palgrave Macmillan.

Roy, A. (2010) Poverty capital: Microfinance and the making of development. Cambridge MA: Harvard University Press.

Skrivankova, K. (2010) Between decent work and forced labour: Examining the continum of exploitation, JRF Programme Paper. York: Joseph Rowntree Foundation.

Steinfeld, R. (2001) Coercion, contract and free labour in the nineteenth century. Cambridge: Cambridge University Press.

Strauss, K. (2012) 'Coerced, forced and unfree labour: Geographies of exploitation in contemporary labour markets’, Geography Compass, 6(3) 137-148.

United Nations (1957) 'Section I: Institutions and practices similar to slavery', in Supplementary Convention On the Abolition of Slavery, the Slave Trade, and Institutions and Practices Similar to Slavery, UN Treaty Series volume 266. Available online at http://treaties.un.org/doc/ publication/UNTS/Volume\%20266/v266.pdf.

United States Department of State (2011) Trafficking in persons report: June 2011. Washington DC: Department of State.

Van der Linden, M. (2008) Workers of the world: Essays toward a global labor history. Leiden: Brill.

Verma, V. (1998) 'Exploitation and justice: Should we be interested in a theory of exploitation?' Economic \& Political Weekly, 33(3): 115-121.

Walk Free (2013) 'The global slavery index report 2013'. Available online at http:/ /www.globalslaveryindex.org.

\section{BIOGRAPHICAL NOTES}

JAMIE MORGAN is a Reader at the School of Accountancy, Finance and Economics at Leeds Beckett University in the UK. [Email: jamiea.morgan@hotmail.co.uk]

WENDY OLSEN is a Reader in Socio-economic Research in the Social Statistics Discipline Area at the University of Manchester in the UK. [Email: wendy.olsen@manchester.ac.uk] 